\author{
${ }^{\odot}$ О. П. Гнатко ${ }^{1}$, Н. Г. Скурятіна ${ }^{1}$, Т. А. Бережна ${ }^{2}$ \\ ${ }^{1}$ Національний медичний університет ілені О. О. Боголольия, Київ \\ ${ }^{2}$ ККЛ ЗТ № 2 Філія «ЦОЗ» ПАТ «Укрзалізниия», Київ

\section{ДІАГНОСТИЧНЕ ЗНАЧЕННЯ МАРКЕРІВ ПРОЛІФЕРАЦІї У ВИЗНАЧЕННІ СТУПЕНЯ ВАЖКОСТІ ПЕРЕДРАКОВИХ СТАНІВ ШИЙКИ МАТКИ}

\begin{abstract}
Мета дослідження - оцінити діагностичне значення маркерів проліферації Р16/Кі-67 у виявленні онкогенної транссрормації при різних ступенях важкості дисплазії шийки матки.

Матеріали та методи. Обстежено 82 жінки віком 24-47 років із дисплазією шийки матки. Крім загальноклінічного обстеження, проводили кольпоскопічне, цитологічне, мікробіологічне та гістологічне дослідження. Специфічні маркери проліферації Р16/Кі-67 визначали імуноцитохімічним методом.

Результати дослідження та їх обговорення. За результатами цитологічного дослідження, CIN I діагностовано у 59 (72,0 \%), CIN II - у 16 (19,5 \%), CIN III - у 7 (8,5 \%) жінок. У всіх пацієнток виявлено атипову кольпоскопічну картину. За результатами ВПЛ-тестування, найбільш часто зустрічався ВПЛ 16 типу (від 25,4 до 100 \%), відмічено високу поширеність ВПЛ 18, 31 і 33 типів при CIN різного ступеня важкості. Позитивні маркери Р16/Кі-67 були виявлені у 10 (16,9 \%) жінок із CIN I, у 9 (56,3 \%) - з CIN II і у 6 (85,7 \%) - з CIN III. Зіставлення результатів цитологічного та гістологічного досліджень у пацієнток із позитивними маркерами P16/Ki-67 показало, що з 10 жінок із CIN I у 4 (40,0 \%) діагностовано CIN II і у 5 (50,0 \%) CIN III; із 9 пацієнток із CIN II - у 6 (66,7 \%) виявлено CIN III; у 3 (50,0 \%) жінок із CIN III підтверджено діагноз, у 1 (16,7 \%) діагностовано Ca in situ, у 2 (33,3 \%) - інвазивний рак. Отже, цитологічний метод дослідження в поєднанні з ВПЛ-тестуванням не дозволив в 17,1 \% випадків діагностувати важкі інтраепітеліальні ураження шийки матки.

Висновки. Комплексне обстеження з включенням цитологічного дослідження і ВПЛ-тестування доцільно доповнювати визначенням специфрічних маркерів проліферації. Це дозволяє встановити інтегративну стадію змін вірусу, яка має онкогенний потенціал, верифікувати ступінь важкості диспластичних змін в епітелії шийки матки, що є важливим для ранньої
\end{abstract} діагностики раку шийки матки.

Ключові слова: шийка матки; маркери проліферації; кольпоскопія; цитологічне дослідження.

ДИАГНОСТИЧЕСКОЕ ЗНАЧЕНИЕ МАРКЕРОВ ПРОЛИФЕРАЦИИ В ОПРЕДЕЛЕНИИ СТЕПЕНИ ТЯЖЕСТИ ПРЕДРАКОВЫХ СОСТОЯНИЙ ШЕЙКИ МАТКИ

Цель исследования - оценить диагностическое значение маркеров пролиферации Р16/Кі-67 в выявлении онкогенной трансорормации при различных степенях тяжести дисплазии шейки матки.

Материалы и методы. Обследовано 82 женщины в возрасте 24-47 лет с дисплазией шейки матки. Кроме общеклинического обследования, проведено кольпоскопическое, цитологическое, микробиологическое и гистологическое исследования. Маркеры пролисерации Р16/Кі-67 исследовали с помощью иммуноцитохимического метода.

Результаты исследования и их обсуждение. При цитологическом исследовании CIN I диагностировано у 59 (72,0 \%), CIN II - у 16 (19,5 \%), CIN III - у 7 (8,5 \%) женщин. У всех пациенток выявлено атипическую кольпоскопическую картину. По результатам ВПЧ-тестирования, наиболее часто встречался ВПЧ 16 типа (от 25,4 до 100 \%), отмечено высокую распространенность ВПЧ 18, 31 и 33 типов при СIN различной степени тяжести. Положительные маркеры пролиферации Р16/Кі-67 были выявлены у 10 (16,9 \%) женщин с CIN I, у 9 (56,3 \%) - с CIN II и у 6 (85,7 \%) - с CIN III. Сопоставление результатов цитологического и гистологического исследований у пациенток с положительными маркерами Р16/Кі-67 показало, что из 10 женщин с CIN I у 4 (40,0 \%) диагностировано CIN II и у 5 (50,0 \%) - CIN III; из 9 пациенток с CIN II - у 6 (66,7 \%) выявлено CIN III; У 3 (50,0 \%) женщин с CIN III подтвержден диагноз, у 1 (16,7 \%) - выявлено Ca in situ, у 2 (33,3 \%) - инвазивный рак. Таким образом, цитологический метод исследования в сочетании с ВПЧ-тестированием не позволили в 17,1 \% случаев диагностировать тяжелые интраэпителиальные поражения шейки матки.

Выводы. Комплексное обследование с включением цитологического исследования и ВПЧ-тестирования целесообразно дополнять определением специфических маркеров пролиферации. Это позволяет установить интегративную стадию изменений вируса, которая имеет онкогенный потенциал, верифицировать степень тяжести диспластических изменений в эпителии шейки матки, что является важным для ранней диагностики рака шейки матки.

Ключевые слова: шейка матки; маркеры пролиферации; кольпоскопия; цитологическое исследование.

DIAGNOSTIC VALUE OF PROLIFERATION MARKERS IN DETERMINATION OF THE SEVERITY OF PRECANCEROUS CERVICAL CONDITIONS

The aim of the study - to evaluate the diagnostic value of P16/Ki-67 proliferation markers in determination of oncogenic transformation at various severity of cervical dysplasia.

Materials and Methods. 82 women aged 24-47 years with cervical dysplasia of varying severity were examined. In addition to general clinical examination, colposcopic, cytological, microbiological and histological studies were performed. P16/Ki-67 proliferation markers were examined by immunocytochemical method.

Results and Discussion. According to cytological examination CIN I was diagnosed in 59 (72.0\%), CIN II in 16 (19.5\%), CIN III in 7 (8.5\%) women. Atypical colposcopic pattern was revealed in all patients. According to the results of HPV test, the most common HPV type 16 (25.4\% to $100 \%)$, common HPV types 18.31 and 33 at CIN of varying severity were observed. Positive P16/Ki-67 markers were found in 10 (16.9\%) women with CIN I, 9 (56.3 \%) with CIN II and 6 (85.7 \%) with CIN III. Comparison 
of the cytological and histological results in patients with positive P16/Ki-67 markers showed that among 10 women with CIN I, 4 (40.0\%) had CIN II and 5 (50.0 \%) CIN III; among 9 patients with CIN II, 6 (66.7 \%) had CIN III; in 3 (50.0 \%) women with CINIII their diagnosis was confirmed, Ca in situ in 1 (16.7 \%) and invasive cancer in 2 (33.3\%) were diagnosed. Thus, the cytological method combined with HPV test did not allow to diagnose severe intraepithelial cervical lesions in $17.1 \%$.

Conclusions. The comprehensive examination with cytology and HPV test should be supplemented with determination of specific proliferation markers. Thus, an integrative stage of changes in the virus that has an oncogenic potential can be established and the severity of dysplastic changes in the cervical epithelium can be verified. This is important for early diagnosis of cervical cancer.

Key words: cervix; proliferation markers; colposcopy; cytology.

ВСтУП. Патологія шийки матки є одною з актуальних проблем у гінекології, з якою стикаються лікарі амбулаторної ланки. Дисплазія шийки матки, або цервікальна інтраепітеліальна неоплазія (cervical intraepithelial neoplasia, CIN) - це наявність структурної та клітинної атипії (зміна розміру ядра та клітинних органел, порушення диференціювання міжклітинних контактів та ступеня зрілості визначеної кількості клітинних шарів) епітелію шийки матки [1]. Дисплазія епітелію шийки матки належить до передракових станів і в 30 \% випадків може трансфрормуватись у рак шийки матки [2-4].

Рак шийки матки займає друге місце в структурі онкологічних захворювань жіночих статевих органів і третя причина смерті серед жінок після раку молочної залози і раку легенів $[1,2]$. Щорічно у світі реєструється близько 600000 нових випадків раку шийки матки і більш ніж 270000 закінчується летально [1, 2, 5, 6].

До фракторів ризику виникнення передраку і раку шийки матки відносять: ранній початок статевого життя; часту зміну статевих партнерів; травматизацію шийки матки під час абортів або пологів; куріння; гормональні порушення; наявність бактеріальних і вірусних захворювань генітального тракту; порушення імунного статусу [1, 2].

За даними численних досліджень, у виникненні цервікальних інтраепітеліальних неоплазій і раку шийки матки важлива роль належить вірусу папіломи людини (ВПЛ) [1, 2, 5]. Відомо понад 120 типів ВПЛ, більше 40 з них здатні пошкоджувати епітеліальні клітини слизових оболонок статевих органів. ВПЛ поділяють на високоонкогенні $(16,18,31,33$, $35,39,45,46,51,52,53,56,58,59,66,68,73,82)$ та низькоонкогенні $(6,11,40,42,43,44,54,61,70,72,81)$ типи вірусів. Доведено, що рак шийки матки в 99,7 \% асоціюється з ВПЛ високого канцерогенного ризику $[1,2,5]$. Через 3 роки після інфікування ВПЛ CIN II-III розвивається у кожної четвертої жінки (27 \%) [5]. У пацієнток із важкою дисплазією в 63,6 \% випадків виявляється ВПЛ 16 типу, в $7 \%$ - ВПЛ 33 типу, в 6,2\% - ВПЛ 18 типу і в 5,4 \% - ВПЛ 31 типу [7].

Вірусна ДНК здатна персистувати в епітеліальних клітинах у двох формах: епісомальній (репродуктивна стадія) та інтегрованій (інтегративна стадія). На епісомальній стадії відбувається продукція нових вірусів, що сприяє залученню в патологічний процес нових клітин, однак клітини не втрачають контроль над процесами апоптозу. Ця стадія характеризується доброякісним перебігом і $є$ зворотною. У 85 \% ВПЛ-інорікованих жінок спостерігається елімінація вірусу $[1,2,5]$. При інтегрованій стадії ДНК вірусу вбудовується в геном інфікованої клітини. Ця стадія є першим кроком до пухлинного переродження інфрікованих вірусом клітин, розвитку CIN і раку шийки матки $[1,2,5]$.

Наявність ВПЛ може свідчити про можливу злоякісну трансформацію епітелію шийки матки і ризик розвитку раку шийки матки. Це взято за основу алгоритмів використання ВПЛ-тестування в програмах цервікального скринінгу разом із цитологічним дослідженням.

Оптимальне поєднання цитологічного дослідження 3 ВПЛ-тестуванням не дозволяє оцінити ступінь важкості CIN. Після виявлення CIN I-II необхідно виділити в даній групі хворих із переходом вірусної інфекції в інтегровану соорму, пов'язану з ризиком розвитку раку. Покращити якість діагностики та програм скринінгу раку шийки матки можна шляхом доповнення традиційних кольпоскопічного, цитологічного та вірусологічного досліджень визначенням специфрічних клітинних маркерів неоплазії цервікального епітелію $[4,5,8]$. Одним із перспективних методів діагностики ВПЛ-асоційованих уражень шийки матки є визначення маркерів проліферації р16 (білка, що бере участь у життєвому циклі клітини) і Кі-67 (маркера активної проліферації).

Пусковим моментом неопластичного процесу шийки матки є інтеграція ВПЛ у геном клітини, в результаті чого порушується зчитування генів E1 і E2, які регулюють експресію онкобілків E6 і Е7. Експресія специфічних онкопротеїнів E6 і E7 є необхідною умовою злоякісного росту цервікальних клітин. Гени Е6 викликають деградацію білків-супресорів генів р53 і BAX, що обумовлює пригнічення апоптозу і зниження продукції інтерферону [4, 5]. Онкобілок E7 взаємодіє з продуктами гена-супресора ретинобластоми (RB) і сприяє стимуляції клітинної пролісрерації, синтезу р16 [2, 4, 5]. Вірусні онкобілки E6 і E7 негативно впливають на хід клітинного циклу, індукуючи перехід інфрікованих клітин у S-фразу клітинного циклу (в нормі такі клітини мають зазнати апоптичної загибелі) $[2,4,5]$.

Білок р16 пригнічує активність циклін-залежних кіназ, які регулюють G1-сразу клітинного циклу. Експресія цього білка в нормальних клітинах обмежена, однак при ВПлінфекції онкобілок E7 зв'язується з білком супрессором пухлин ретинобластомою (RB), що призводить до її деградації і, в подальшому, обумовлює надлишкову експресію р16 [9]. Білок Кі-67 - маркер клітинної пролісрерації, наявний у клітинах, що знаходяться у фазах клітинного циклу пізній G1, S, G2 і М, але не в клітинах, що знаходяться в стані спокою (в фразі G0 та ранній G1) [4]. Одночасне виявлення р16 (білка, що регулює життєвий цикл клітин) і Кі-67 (маркера клітинної проліфрерації) дозволяє визначити не тільки наявність вірусних білків у клітині, а й ступінь порушень клітинної регуляції у відповідь на персистенцію вірусу в клітині, а також допомагає виявити ВПЛ-інфріковані клітини з онкогенною трансформацією.

МЕТА ДОСЛІДЖЕННЯ - оцінити діагностичне значення маркерів проліферації Р16 і Кі-67 у виявленні онкогенної транссормації при різних ступенях важкості дисплазії шийки матки. 
МАТЕРІАЛИ ТА МЕТОДИ. Обстежено 82 жінки віком 24-47 років із дисплазією шийки матки різного ступеня важкості.

Критерії включення: репродуктивний вік, наявність дисплазії шийки матки, наявність ВПЛ-інфекції, поінформована згода на участь у дослідженні. Критерії не включення: відсутність ВПЛ, вказівки на лікування захворювань шийки матки в анамнезі, відмова від участі в дослідженні.

Обстеження кожної жінки, крім загальноклінічних методів досліджень, відповідно до наказу МОЗ України № 417, включало кольпоскопічне, цитологічне та мікробіологічне дослідження.

При кольпоскопічному дослідженні оцінювали стан епітелію і стикування різних його типів, рельєфр поверхні шийки матки, стан підлеглої сполучної тканини. Розширена кольпоскопія включала огляд та оцінку стану піхвової частини шийки матки при збільшенні в 7-30 разів із використанням низки епітеліальних тестів для визначення реакції тканини у відповідь на обробку розчином Люголя і 3 \% оцтової кислоти.

Проведення розширеної кольпоскопії дозволяє не тільки визначити стан епітелію та судин, стан стикування епітелію шийки матки і цервікального каналу, а й виділити наявність патологічних вогнищ та їх межі, що дозволяє правильно, при необхідності, визначати місце біопсії, вибирати найбільш безпечні методи лікування для збереження максимального об'єму шийки матки, особливо в жінок, що не народжували.

Просту та розширену кольпоскопію з використанням тестів з 3-5 \% розчином оцтової кислоти і 3 \% водним розчином Люголя (проба Шиллера) проводили на апараті МК-200 (Україна). Оцінку кольпоскопічних картин обстежених жінок проводили відповідно до Міжнародної класифікації кольпоскопічних термінів (2011 рік, Ріо-деЖанейро)

Цитологічне дослідження є скринінговим методом у програмах профрілактики раку шийки матки. Цитологічне дослідження мазків із цервікального каналу і шийки матки оцінювали за Папаніколау (Pap-smear-test).

Інфекційний скринінг включав результати оцінки мазків при бактеріоскопічному дослідженні, метод полімеразної ланцюгової ракції (ПЛР-діагностику), культуральний метод для ідентифрікації мікрофрлори та визначення чутливості до антибіотиків [10]. Для виявлення уреаплазм та мікоплазм застосовували тест-системи Mycoplasma DUO. Хламідії та вірус папіломи людини (ВПЛ) виявляли методом ПЛР. Крім того, при визначенні ВПЛ визначали вірусне навантаження за допомогою ПлР-кількісного методу.

Специфрічні маркери проліферації Р16 і Кі-67 визначали імуноцитохімічним методом із використанням тестсистем CINtec PLUS (Roche, Швейцарія).

Для підтвердження дисплазії проводили гістологічне дослідження біопсійного матеріалу шийки матки.

Статистичну обробку отриманих даних здійснювали за допомогою стандартних програм статистичного аналізу (GraphPad Insstant, Stastica for Windows v.7.0, Microsoft Excel 2003 та ін.), оцінюючи вірогідність за допомогою критерію t Стьюдента.

РЕЗУЛЬТАТИ ДОСЛІДЖЕННЯ ТА ЇХ ОБГОВОРЕННЯ. Середній вік обстежених жінок становив $(33,7 \pm 0,58)$ року.
За даними гінекологічного анамнезу, встановлено, що більшість жінок - 61 (74,4 \%) мали своєчасне настання менархе, ранній початок статевого життя мали 68 (82,9\%) пацієнток. Серед перенесеної гінекологічної патології зустрічались запальні захворювання статевого тракту -у 8 (9,8 \%) жінок, гіперпластичні процеси ендометрія - у 17 (20,7\%), пухлини яєчників - у 3 (3,7 \%), лейоміома матки - у 23 (28,0 \%) і ендометріоз - у 8 (9,8 \%) пацієнток.

Оцінка репродуктивної функції показала, що 74 (90,2 \%) жінки мали вагітності, які закінчились пологами у 71 (86,6\%), штучними абортами - у 28 (34,1 \%) і самовільними викиднями - у 8 (9,8 \%) жінок.

Об'єктивні та додаткові методи обстеження жінок із дисплазією шийки матки показали наступне.

За результатами цитологічного дослідження матеріалу, що забрано з цервікального каналу і піхвової частини шийки матки, CIN I діагностовано у 59 (72,0 \%), CIN II - у 16 (19,5\%), CIN III - у 7 (8,5 \%) жінок.

При проведенні кольпоскопії були виявлені зміни епітелію шийки матки, характеристика яких представлена в таблиці 1.

Аналіз представлених даних показав, що всі пацієнтки мали атипову кольпоскопічну картину. У більшості жінок з CIN I - $58(98,3$ \%) і у $13(81,3$ \%) з CIN II відмічено незначні ураження епітелію шийки матки (тонкий оцтобілий епітелій, ніжна мозаїка, ніжна пунктація). Значні ураження епітелію шийки матки (щільний оцтобілий епітелій, груба мозаїка, груба пунктація) виявлено у більшості пацієнток iз CIN III - y $6(85,7 \%)$.

Результати лабораторного скринінгу показали, що у всіх обстежених жінок виявлено типи ВПЛ високого канцерогенного ризику (табл. 2).

Як свідчать дані таблиці, найбільш часто зустрічався ВПЛ 16 типу у пацієнток із дисплазією різного ступеня важкості (з CIN I - у 25,4 \%, з CIN II - у 37,5 \%, і у всіх жінок з CIN III). Також відмічено високу поширеність ВПЛ 18, 31 і 33 типів при CIN різного ступеня важкості. Рідше виявлялись 35, 45, 51, 56, 66 і 68 типи ВПЛ.

Подальший аналіз показав, що одночасне інсікування двома високоонкогенними типами ВПЛ відмічено у 13 (22,0 \%) жінок з CIN I, у 8 (50,0 \%) - 3 CIN II і у 6 (85,7 \%) з CIN III; одночасне інфікування трьома типами ВПЛ діагностовано у 3 (5,1 \%), 3 (18,8 \%) і 1 (14,3 \%) пацієнток відповідно.

За допомогою кількісного фрормату ПЛР встановлено, що ВПЛ з високим вірусним навантаженням (кількість геномних елементів (ГЕ) більше ніж $10^{5}$ на 100 тисяч клітин) діагностовано у 31 (52,5\%) жінок із CIN I, у 13 (81,3\%) - 3 CIN II і у всіх пацієнток із CIN III. Високе вірусне навантаження асоціюється з ризиком розвитку важкої дисплазії і раку шийки матки.

Результати мікробіологічних досліджень показали, що в жінок із дисплазіями шийки матки, крім ВПЛ, виявлялись бактеріальні збудники урогенітальних інфекцій (табл. 3).

Серед збудників урогенітальних інфекцій переважали Ureaplasma urealiticum, Gardnerella vaginalis і гриби роду Candida у жінок із дисплазією шийки матки різного ступеня важкості. Аналіз бактеріологічного дослідження показав, що у 21 (35,6 \%) пацієнтки з CIN I, у 7 (43,8 \%) - з CIN II i у 4 (57,1\%) - 3 CIN III були присутні представники неспецифрічної мікрофрлори (Е. coli, St. aureus, St. epidermalis, Enterococcusfaecalis, Str. Anhaemalithicus) у високому 
Таблиця 1. Частота і форми атипової кольпоскопічної картини в обстежених жінок (абс. число, \%)

\begin{tabular}{|c|c|c|c|c|c|c|}
\hline \multirow{3}{*}{ Кольпоскопічна картина } & \multicolumn{6}{|c|}{ Пацієнтки з дисплазією шийки матки } \\
\hline & \multicolumn{2}{|c|}{ CIN I, n=59 } & \multicolumn{2}{|c|}{ CIN II, n=16 } & \multicolumn{2}{|c|}{ CIN III, n=7 } \\
\hline & абс. число & $\%$ & абс. число & $\%$ & абс. число & $\%$ \\
\hline Ніжна мозаїка & 42 & 71,2 & 10 & 62,5 & - & - \\
\hline Тонкий оцтобілий епітелій & 9 & 15,3 & - & - & - & - \\
\hline Ніжна мозаїка + ніжна пунктація & - & - & - & - & 1 & 14,3 \\
\hline Груба мозаїка & - & - & 2 & 12,5 & 4 & 57,2 \\
\hline Ніжна пунктація & - & - & 3 & 18,8 & - & - \\
\hline $\begin{array}{l}\text { Ніжна мозаїка + тонкий оцтобілий } \\
\text { епітелій }\end{array}$ & 5 & 8,5 & - & - & - & - \\
\hline $\begin{array}{l}\text { Ніжна мозаїка + щільний оцтобілий } \\
\text { епітелій }\end{array}$ & 1 & 1,7 & 1 & 6,3 & - & - \\
\hline $\begin{array}{l}\text { Поліп цервікального каналу + тон- } \\
\text { кий оцтобілий епітелій }\end{array}$ & 2 & 3,4 & - & - & - & - \\
\hline Груба пунктація & - & - & - & - & 1 & 14,3 \\
\hline $\begin{array}{l}\text { Поліп цервікального каналу + груба } \\
\text { мозаїка }\end{array}$ & - & - & - & - & 1 & 14,3 \\
\hline
\end{tabular}

Таблиця 2. Частота виявлення типів ВПл в обстежених жінок (абс. число, \%)

\begin{tabular}{|c|c|c|c|c|c|c|}
\hline \multirow{3}{*}{ Тип ВПЛ } & \multicolumn{6}{|c|}{ Пацієнтки з дисплазією шийки матки } \\
\hline & \multicolumn{2}{|c|}{ CIN I, n=59 } & \multicolumn{2}{|c|}{ CIN II, n=16 } & \multicolumn{2}{|c|}{ CIN III, n=7 } \\
\hline & абс. число & $\%$ & абс. число & $\%$ & абс. число & $\%$ \\
\hline 16 & 15 & 25,4 & 6 & 37,5 & 7 & 100,0 \\
\hline 18 & 10 & 16,9 & 4 & 25,0 & 2 & 28,6 \\
\hline 31 & 3 & 5,1 & 3 & 18,8 & 2 & 28,6 \\
\hline 33 & 8 & 13,6 & 1 & 6,3 & 2 & 28,6 \\
\hline 35 & 7 & 11,9 & 3 & 18,8 & - & - \\
\hline 45 & 2 & 3,4 & 2 & 12,5 & - & - \\
\hline 51 & 9 & 15,3 & 2 & 12,5 & 1 & 14,3 \\
\hline 56 & 4 & 6,8 & 1 & 6,3 & 1 & 14,3 \\
\hline 66 & 7 & 11,9 & - & - & - & - \\
\hline 68 & 2 & 3,4 & 1 & 6,3 & 1 & 14,3 \\
\hline
\end{tabular}

Таблиця 3. Структура і частота видового спектра бактеріальних збудників урогенітальних інфекцій в обстежених жінок (абс. число, \%)

\begin{tabular}{|c|c|c|c|c|c|c|}
\hline \multirow{3}{*}{ Вид збудника } & \multicolumn{6}{|c|}{ Пацієнтки з дисплазією шийки матки } \\
\hline & \multicolumn{2}{|c|}{ CIN I, n=59 } & \multicolumn{2}{|c|}{ CIN II, n=16 } & \multicolumn{2}{|c|}{ CIN III, n=7 } \\
\hline & абс. число & $\%$ & абс. число & $\%$ & абс. число & $\%$ \\
\hline Ureaplasma urealiticum & 14 & 23,7 & 2 & 12,5 & 2 & 28,6 \\
\hline Chlamydia trachomatis & 2 & 3,4 & 1 & 6,3 & - & - \\
\hline Gardnerella vaginalis & 13 & 22,0 & 2 & 12,5 & - & - \\
\hline Trichomonas vaginalis & 4 & 6,8 & 2 & 12,5 & 1 & 14,3 \\
\hline Гриби роду Candida & 12 & 20,3 & 4 & 25,0 & 3 & 42,9 \\
\hline
\end{tabular}

мікробному числі (105-106 КУО/г). Слід зазначити, що частота виявлення як специсрічних, так і неспециорічних збудників була вищою у пацієнток із більш важким ступенем дисплазії. Отже, наявність тривалої хронічної бактеріальної інфекції в поєднанні з ВПЛ сприяє поглибленню атипових змін епітелію шийки матки.

Аналіз результатів визначення клітинних маркерів проліферації показав, що у 10 (16,9 \%) жінок із CIN I, у 9 (56,3 \%) - 3 CIN II і у $6(85,7 \%)-3$ CIN III діагностовано позитивні маркери проліферації Р16/Кi-67. Розподіл ге- нотипів ВПЛ у пацієнток із позитивними Р16/Кі-67 представлено в таблиці 4.

Результати отриманих даних свідчать, що найбільш часто у пацієнток із позитивними клітинними маркерами виявлялись ВПЛ 16, 18 і 31 генотипи. Отримані дані збігаються з даними літератури, про те що в 70 \% випадків важка дисплазія асоціюється з ВПл 16 і 18 типів [1, 5]. У жінок із позитивними маркерами проліфрерації одночасне інфікування двома типами ВПЛ діагностовано у 5 (50,0 \%) при CIN I, у 4 (44,4 \%) - при CIN II i y 4 (66,7 \%) - при CIN 


\section{Акушерство та гінекологія}

Таблиця 4. Частота виявлення генотипів ВПЛ у жінок із позитивними маркерами проліферації Р16/Ki-67 (абс. число, \%)

\begin{tabular}{|c|c|c|c|c|c|c|}
\hline \multirow{3}{*}{ Тип ВПЛ } & \multicolumn{6}{|c|}{ Пацієнтки з дисплазією шийки матки } \\
\hline & \multicolumn{2}{|c|}{$\mathrm{CIN} \mathrm{I,} \mathrm{n=10}$} & \multicolumn{2}{|c|}{ CIN II, n=9 } & \multicolumn{2}{|c|}{ CIN III, n=6 } \\
\hline & абс. число & $\%$ & абс. число & $\%$ & абс. число & $\%$ \\
\hline 16 & 6 & 60,0 & 4 & 44,4 & 6 & 100,0 \\
\hline 18 & 3 & 30,0 & 3 & 33,3 & 3 & 50,0 \\
\hline 31 & 2 & 20,0 & 2 & 22,2 & 1 & 16,7 \\
\hline 33 & 1 & 10,0 & 1 & 11,1 & 1 & 16,7 \\
\hline 35 & 1 & 10,0 & 1 & 11,1 & - & - \\
\hline
\end{tabular}

III. Найбільш часто зустрічались поєднання 16 і 18 типів ВПЛ - у $3(30,0 \%)$ при CIN I, у 2 (22,2\%) - при CIN II, у 3 (50,0 \%) - при CIN III; рідше виявлялись поєднання 16 і 31 типів та 16 і 33 типів. У всіх пацієнток із позитивними Р16/ Кі-67 ВПЛ виявлялись у високому вірусному навантаженні.

Для підтвердження ступеня важкості дисплазії всім пацієнткам забрано матеріал із змінених ділянок шийки матки для гістологічного дослідження. Результати гістологічного дослідження були наступними: CIN I діагностовано у 50 (61,0 \%) жінок, CIN II - у 14 (17,1 \%), CIN III - y 15 (18,3\%), Ca in situ - у 1 (1,2\%) та інвазивний рак - у 2 (2,4 \%) жінок. Тобто результати гістологічного дослідження не збігалися 3 попередніми даними цитологічного дослідження.

Зіставлення результатів цитологічного та гістологічного досліджень у пацієнток із позитивними маркерами проліфрерації P16/Ki-67 показало, що з 10 жінок із CIN I у 4 (40,0 \%) діагностовано CIN II і у 5 (50,0 \%) - CIN III (табл. 5). Морфологічні результати 9 пацієнток із CIN II показали наявність CIN III у 6 (66,7 \%). У 3 (50,0 \%) жінок із CIN III підтверджено діагноз, у 1 (16,7 \%) - діагностовано Ca in situ, у 2 (33,3\%) - інвазивний рак.

Як свідчать дані таблиці, цитологічний метод дослідження в поєднанні з ВПЛ-тестуванням не дозволили у $14(17,1 \%)$ жінок діагностувати важкі інтраепітеліальні ураження шийки матки (у 5 (8,5 \%) - 3 CIN I, у 6 (37,5 \%) - 3 CIN II і у 3 (42,9 \%) - 3 CIN III). Доповнення вказаних методів визначенням специфічних маркерів проліферації $€$ важливим для ранньої діагностики раку шийки матки, а також дозволяє оцінити потенціал дисплазії у відношенні розвитку раку шийки матки і вибрати адекватну тактику лікування.

Таблиця 5. Зіставлення результатів цитологічного та гістологічного досліджень у жінок із позитивними Р16/Кі-67 (абс. число, \%)

\begin{tabular}{|l|c|c|}
\hline Результати цитологічного дослідження & \multicolumn{2}{|c|}{ Результати гістологічного дослідження } \\
\hline \multirow{3}{*}{ CIN I, n=10 } & CIN I & $1(10,0 \%)$ \\
\cline { 2 - 3 } & CIN II & $4(40,0 \%)$ \\
\cline { 2 - 3 } & CIN III & $5(50,0 \%)$ \\
\hline \multirow{2}{*}{ IIN II, n=9 } & CIN II & $3(33,3 \%)$ \\
\cline { 2 - 3 } & CIN III & $6(66,7 \%)$ \\
\hline \multirow{3}{*}{ IIN III, n=6 } & CIN III & $1(16,0 \%)$ \\
\cline { 2 - 3 } & Ca in situ & $2(33,3 \%)$ \\
\cline { 2 - 3 } & інвазивний рак & $2(16,7)$ \\
\hline
\end{tabular}

ВИСновкИ. 1. Маркери пролісрерації Р16 і Кі-67 є важливим неінвазивним діагностичним тестом, що дозволяє встановити інтегративну стадію змін вірусу, яка має онкогенний потенціал, та верифрікувати ступінь важкості диспластичних зміни в епітелії шийки матки.

2. Комплексне обстеження з включенням цитологічного дослідження і ВПЛ-тестування доцільно доповнювати визначенням маркерів проліферації Р16 і Кі-67, що дозволяє вибирати своєчасну і ефективну лікувальну тактику при дисплазії шийки матки у жінок репродуктивного віку.

ПЕРСПЕКТИВИ ПОДАЛЬШИХ ДОСЛІДЖЕНЬ. ФОрмування діагностичного алгоритму при патології шийки матки для виявлення потенційно небезпечних станів і визначення оптимальної лікувальної тактики.

\section{СПИСОК ЛІТЕРАТУРИ}

1. Фоновые и предраковые заболевания шейки матки : учебное пособие / под ред. О. Е. Баряева. - Иркутск : ИГМУ, 2012. -40 c.

2. Кондратюк В. К. Дисплазія епітелію шийки матки: етіологія, патогенез, діагностика, лікування / В. К. Кондратюк, Н. Є. Горбань, А. І. Нарольська // Репродуктивная эндокринология. - 2014. - № 3 (17). - С. 105-109.
3. Kovanda A. Pre-vaccination distribution of human papillomavirus (HPV) genotypes in women with cervical intraepithelial neoplasia grade 3 (CIN 3) lesions in Slovenia / A. Kovanda, U. Juvan, A. Sterbenc // Acta Dermatovenerol. Alp. Panonica Adriat. - 2009. - 18 (2). - P. 47-52.

4. Короленкова Л. И. Молекулярно-биологические маркеры пролиферации и апоптоза как фракторы пролиферации 
цервикальных интраэпителиальных неоплазий шейки матки / Л. И. Короленкова, Е. В. Степанова, А. Ю. Борышников // Российский биотерапевтический журнал. - 2010. - Т. 9, № 4. - C. 11-16.

5. Новые возможности ранней диагностики и профилактики ВПЧ-ассоциированных поражений шейки матки / В. Н. Прилепская, Г. Р. Байрамова, Е. А. Коган, В. Ф. Чернова // Медицинский совет. Гинекология. - 2015. - С. 72-76.

6. Жилка Н. Я. Епідеміологія раку шийки матки в Україні / Н. Я. Жилка, Т. В. Зайкова // Україна. Здоров'я нації. - 2012 - № 4 (24). - C. 40-47.

7. Giannella L. Age-related changes in the diagnostic assessment of women with severe cervical lesions / L. Giannella,

\section{REFERENCES}

1. Baryaeva, O.E. (Ed.). (2012). Fonovye i predrakovye zabolevaniya sheyki matki: uchebnoye posobie [Background and precancerous cervical diseases]. Irkutsk: IGMU [in Russian].

2. Kondratiuk, V.K., Horban, N.Ye., \& Narolska, A.I (2014). Dysplasiia epiteliia shyiky matky: etiolohiia, diahnostyka, likuvannia [Cervical epithelial dysplasia: etiology, diagnostics, treatment]. Reproduktyvna endokrynolohiia - Reproductive Endocrinology, 3(17), 105-109 [in Ukrainian].

3. Kovanda, A., Juvan, U., \& Sterbenc, A. (2009). Prevaccination distribution of human papillomavirus (HPV) genotypes in women with cervical intraepithelial neoplasia grade 3 (CIN 3) lesions in Slovenia. Acta Dermatovenerol. Alp. Panonica Adriat., 18 (2), 47-52.

4. Korolenkova, L.I. (2010). Molekuliarno-biologicheskie markery proliferatsii i apoptoza kak faktory proliferatsii tservikalnykh intraepitelialnykh neoplazii sheyki matki [Molecularbiological markers of proliferation and apoptosis as factors of proliferation of intraepithelial cervical neoplasia]. Rossiyskiy bioterapevticheskiy zhurnal - Russian Bio-therapeutic Journal, 9 (4), 11-16 [in Russian].

5. Prilepskaya, V.N., Bayramova, G.R., Kogan, E.A., \& Chernova, V.F. (2015). Novye vozmozhnosti ranney diagnostiki i profilaktiki VPCh-assotsiirovannykh porazheniy sheyki matki
C. Fodero, F. Boselli // Climacteric. - 2015. - Vol. 18, No. 4. P. 617-623.

8. Grigore M. Molecular markers in cervical screening a promise for the future. Utilitatea markerilor moleculari în screening-ul cancerului de col uterin / M. Grigore, S. Teleman, D. Ungureanu // Romanian Review of Laboratory Medicine. 2013. - Vol. 21, No. 2/4. - P. 231-239.

9. Bergeron C. Conjunctive p16 (INK4a) testing significantly increases accuracy in diagnosing high-grade cervical intraepithelial neoplasia / C. Bergeron, J. Ordi, D. Schmidt // Am. J. Clin. Pathol. - 2010. - No. 133 (3). - P. 395-406.

10. Медицинская лабораторная диагностика (программы и алгоритмы). Т. 3 / под ред. А. И. Карпищенко. - СПб. : Интермедика, 2001. - 544 с.

[New opportunities for early diagnosis and prevention of HPVassociated cervical lesions]. Meditsinskiy sovet. Ginekologiya - Medical Council. Gynecology, 72-76 [in Russian].

6. Zhylka, N.Ya., \& Zaikova, T.V. (2012) Epidemiolohiia raku shyiky matky $v$ Ukraini [Epidemiology of cervical cancer in Ukraine]. Ukraina. Zdorovia natsii - Ukraine. Nation Health, 4 (24), 40-47 [in Ukrainian].

7. Giannella, L., Fodero, C., Boselli, F. (2015). Age-related changes in the diagnostic assessment of women with severe cervical lesions. Climacteric, 18, 4, 617-623.

8. Grigore, M., Teleman, S., \& Ungureanu, D. (2013). Molecular markers in cervical screening - a promise for the future [Utilitatea markerilor moleculari în screening-ul cancerului de col uterin]. Romanian Review of Laboratory Medicine, 21, 2/4, 231-239.

9. Bergeron, C., Ordi, J., Schmidt, D., \& Bergeron, C. (2010). Conjunctive p16 (INK4a) testing significantly increases accuracy in diagnosing high-grade cervical intraepithelial neoplasia. Am. J. Clin. Pathol, 133 (3), 395-406.

10. Karpishchenko, A.I. (Ed.). (2001). Meditsinskaya laboratornaya diagnostika (programmy i algoritmy [Medical laboratory diagnostics (programs and algorithms)]. Saint-Petersburg: Intermedika [in Russian]. 